\title{
Study of Genetic Diversity among Elite Genotypes of Rice (Oryza sativa L.) for Direct Seeding Traits
}

\author{
Ravikanth Bendi $^{1 *}$, P.V. Satyanarayana ${ }^{2}$, N. Chamundeswari ${ }^{2}$, Y. Ashoka Rani ${ }^{3}$, \\ V. Srinivasa $\operatorname{Rao}^{3}$ and D. Ratna Babu ${ }^{3}$
}

${ }^{1}$ Department of Genetics \& Plant Breeding, Agricultural College, Bapatla, Guntur, A.P., 522 101, India

${ }^{2}$ Regional Agricultural Research Station, Maruteru, West Godavari, A.P., 534 122, India

${ }^{3}$ Agricultural College, Bapatla, ANGRAU, Guntur, A.P., 522 101, India

*Corresponding author

\section{A B S T R A C T}

\section{Keywords}

Genetic diversity,

$\mathrm{D}^{2}$ Analysis, Direct seeded rice

Article Info

Accepted:

10 August 2018

Available Online:

10 September 2018
An experiment was carried out with 48 elite rice genotypes to study genetic diversity for direct seeding traits. They were evaluated for 19 characters consisting of 13 agronomical and six physiological using Mahalanobis $\mathrm{D}^{2}$ statistics. On the basis of $\mathrm{D}^{2}$ values the genotypes were grouped into eight clusters. Cluster I and VI were the largest containing 15 and 12 genotypes respectively followed by cluster III with 6 and cluster V with 4 genotypes. The maximum inter-cluster distance was recorded between clusters VII and VIII (11832.91) and the maximum intra-cluster distance was found in cluster IV (841.80) followed by cluster III (823.07). The characters like test weight $(46.99 \%)$, vigour index $(34.57 \%)$, plant height $(12.23)$ and number of total grains panicle ${ }^{-1}(1.68 \%)$ contributed maximum towards genetic diversity. Therefore these characters could be given due importance for selection of genotypes suitable for direct seeding in rice. Genotypes from the clusters VII and VIII, III and VIII, I and VIII will result in superior segregants.

\section{Introduction}

Rice (Oryza sativa L.) is the most important staple food crop in the world and provides food and livelihood security to over half of the global population. Ranking first in area (44.11 $\mathrm{m} \mathrm{ha})$, India (105.5 $\mathrm{m} \mathrm{t}$ ) is the second largest producing country in the world after China with a productivity of $2.39 \mathrm{t} \mathrm{ha}^{-1}$ (http:// ricestat.irri.org).

The productivity and sustainability of ricebased systems are threatened because of the increasing scarcity of resources, especially water and labor; changing climate; the emerging energy crisis and the rising cost of cultivation (Ladha et al., 2009). Under the situation of water and labour scarcity, farmers are changing their rice establishment method from transplanting to direct seeding.

Direct seeded rice requires specially bred cultivars having early seedling vigour for weed competitiveness, efficient root system for anchorage. Ability to germinate under anaerobic conditions and tolerance of early 
submergence are important for establishing a good direct seeded rice crop (Ismail et al., 2009). Lodging resistance is another desirable trait for direct seeding.

Genetic divergence is a useful tool for an efficient choice of parents for hybridization to develop high yield potential cultivars. Mahalanobis' $\mathrm{D}^{2}$ statistics is an effective tool in quantifying the degree of genetic divergence at the genotypic level. The use of Mahalanobis $\mathrm{D}^{2}$ statistic for estimating genetic divergence has been emphasized by Shukla et al., (2006) and Sandhya et al., (2015).

Thus the present investigation was intended to assess the genetic diversity among the genotypes studied for the traits related to direct seeding and yield. The hybrids between genotypes of different clusters will express high heterosis and give more useful segregants. Further, one or two genotypes from different clusters may be chosen for further genetic studies either by diallel or line $\times$ tester analysis.

\section{Materials and Methods}

\section{Experimental site}

The present investigation was carried out at Andhra Pradesh Rice Research Institute (APRRI) and Regional Agricultural Research Station (RARS), Maruteru, West Godavari, Andhra Pradesh, India, located at an altitude of $5 \mathrm{~m}$ above MSL, $81.44^{0} \mathrm{E}$ longitude and $26.38^{0} \mathrm{~N}$ latitude. The soils are characterized by black alluvial soils, neutral to slightly alkaline in reaction with medium levels of phosphorus and potassium. The annual rainfall of the location is $1100 \mathrm{~mm}$.

\section{Experimental material}

The experimental material for the present investigation comprised of 48 genotypes of rice including varieties, advanced breeding lines and germplasm lines.

\section{Recording of observations and data analysis}

The data on 19 characters consisting of 13 agronomical [days to $50 \%$ flowering, plant height $(\mathrm{cm})$, leaf area index, number of productive tillers per plant, total number of tillers per $\mathrm{m}^{2}$, panicle length $(\mathrm{cm})$, number of filled grains per panicle, number of total grains per panicle, spikelet fertility (\%), test weight (g), grain yield per plant (g), biological yield per plant (g) and harvest index] and six physiological [Standard germination test using paper towel was conducted to record seedling root length $(\mathrm{mm})$, seedling root length $(\mathrm{mm})$, rate of germination (\%), seedling vigour index (measured as per Abdul-baki and Anderson, 1973), anaerobic germination (\%) (As per Manigbas et al., 2008) and basal culm diameter $(\mathrm{mm})$ measured at $4^{\text {th }}$ internode from top using Vernier callipers one week before harvesting] was recorded standard methods. Data was analyzed following multivariate analysis of Mahalanobis (1936) and genotypes were grouped into different clusters following Tocher's method (Rao, 1952).

\section{Results and Discussion}

The multivariate analysis like Mahalanobis' $\mathrm{D}^{2}$ statistic provides useful statistical tool for measuring the genetic diversity in a given population with respect to the characters that were considered together. The data collected on 19 yield and direct seeding characters from 48 genotypes of rice were subjected to Mahalanobis' analysis. The magnitude of values suggested that there was considerable variability in the genotypes studied, which led to genetic diversity. Significant differences among the genotypes for individual characters were first determined and later the statistical significant differences between the genotypes 
based on the pooled effects of all the characters were carried out using the ' $\mathrm{V}$ ' statistic. The statistic was highly significant indicating that genotypes differ significantly. The value of ' $\mathrm{V}$ ' statistic was 2852.26 in the present investigation.

The per cent contribution towards genetic divergence for all the 19 contributing characters is presented in Table 1. The knowledge on characters influencing divergence is an important aspect to a breeder. Character-wise rank has shown maximum contribution towards genetic divergence was by test weight $(46.99 \%)$ followed by vigour index (34.57\%), plant height (12.23\%), number of total grains per panicle $(1.68 \%)$, spikelet fertility $(1.51 \%)$, basal culm diameter $(1.33 \%)$, rate of germination $(0.77 \%)$, harvest index $(0.35 \%)$ and total number of tillers per $\mathrm{m}^{2}(0.18 \%)$. Maximum contribution of test weight, plant height and number of grains per panicle was also reported by Pandey and Anurag (2010); Soni et al., (2014).

The 48 genotypes were grouped into eight clusters using the Tocher's method with the criterion that the intra-cluster average $\mathrm{D}^{2}$ values should be less than the inter-cluster $\mathrm{D}^{2}$ values (Table 2). The distribution of 48 genotypes into eight clusters was at random with maximum number of genotypes in cluster I (15 genotypes) from different locations. Cluster II was the second largest with 12 genotypes followed by cluster III (eight genotypes), cluster IV (six genotypes) and cluster V (four genotypes). Clusters VI, VII and VIII were solitary clusters.

Table.1 Contribution of different characters towards genetic divergence in 48 rice genotypes

\begin{tabular}{|c|c|c|c|}
\hline $\begin{array}{l}\text { S. } \\
\text { No. }\end{array}$ & Character & $\begin{array}{l}\text { No. of times } \\
\text { ranked first }\end{array}$ & $\begin{array}{c}\text { Per cent } \\
\text { contribution }\end{array}$ \\
\hline 1 & Days to $50 \%$ flowering & 0.000 & 0.01 \\
\hline 2 & Plant height $(\mathrm{cm})$ & 138.000 & 12.23 \\
\hline 3 & Leaf area index & 1.000 & 0.09 \\
\hline 4 & Number of productive tillers plant ${ }^{-1}$ & 0.000 & 0.01 \\
\hline 5 & Total number of tillers $\mathrm{m}^{-2}$ & 2.000 & 0.18 \\
\hline$\overline{6}$ & Panicle length $(\mathrm{cm})$ & 0.000 & 0.01 \\
\hline 7 & Number of filled grains per panicle & 0.000 & 0.01 \\
\hline 8 & Number of total grains per panicle & 19.000 & 1.68 \\
\hline 9 & Spikelet fertility (\%) & 17.000 & 1.51 \\
\hline 10 & Test weight (g) & 530.000 & 46.99 \\
\hline 11 & Grain yield per plant $(\mathrm{g})$ & 0.000 & 0.01 \\
\hline 12 & Biological yield per plant $(\mathrm{g})$ & 1.000 & 0.09 \\
\hline 13 & Harvest index (\%) & 4.000 & 0.35 \\
\hline 14 & Anaerobic germination (\%) & 0.000 & 0.01 \\
\hline 15 & Seedling root length $(\mathrm{mm})$ & 3.000 & 0.27 \\
\hline 16 & Seedling shoot length $(\mathrm{mm})$ & 0.000 & 0.01 \\
\hline 17 & Rate of germination (\%) & 8.000 & 0.71 \\
\hline 18 & Seedling vigor index & 390.000 & 34.57 \\
\hline 19 & Basal culm diameter $(\mathrm{mm})$ & 15.000 & 1.33 \\
\hline
\end{tabular}


Table. 2 Clustering pattern of 48 rice genotypes by Tocher's method

\begin{tabular}{|c|c|c|}
\hline $\begin{array}{l}\text { Cluster } \\
\text { No. }\end{array}$ & $\begin{array}{l}\text { No. of } \\
\text { genotypes }\end{array}$ & Name of genotype(s) \\
\hline I & 15 & $\begin{array}{l}\text { MTU 1061, DP 25, PLA 1100, JGL 384, RGL 2537, MTU 1081, } \\
\text { BPT 3291, MTU 1078, BPT 2270, MTU 1140, MTU 2077, MTU } \\
\text { 1064, IR 50, RATNA, RGL } 2332\end{array}$ \\
\hline II & 12 & $\begin{array}{l}\text { ANJALI, KALINGA-III, MTU 1010, WAYRAREM, IR } 72 \text {, } \\
\text { SABITA, AC 39813, SHABAGIDHAN, MTU 1156, L 44, } \\
\text { VANDANA, IR } 64\end{array}$ \\
\hline III & 8 & $\begin{array}{l}\text { RNR 15048, NA VEEN, MTU 1075, MTU 1166, MTU 1112, JGL } \\
\text { 17004, MTU 1121, E } 412\end{array}$ \\
\hline$\overline{\mathbf{I V}}$ & 6 & AC 34245, AC 34345, AZUCENA, AC 34280, AC 39397, PS-140-1 \\
\hline$\overline{\mathbf{V}}$ & 4 & ANNADA, IRS-3, IR 36, MTU 3626 \\
\hline$\overline{\mathbf{V I}}$ & 1 & N 22 \\
\hline$\overline{\text { VII }}$ & 1 & BPT 5204 \\
\hline VIII & 1 & AC 39416A \\
\hline
\end{tabular}

Table.3 Average intra (diagonal) and inter-cluster $\mathrm{D}^{2}$ and $\mathrm{D}$ values (within parenthesis) values among eight clusters in 48 rice genotypes

\begin{tabular}{|c|c|c|c|c|c|c|c|c|}
\hline $\begin{array}{c}\text { Cluster } \\
\text { Numbe } \\
\text { r }\end{array}$ & I & II & III & IV & $\mathbf{V}$ & VI & VII & VIII \\
\hline I & $\begin{array}{l}418.66 \\
(20.46)\end{array}$ & $\begin{array}{c}1084.66 \\
(32.934)\end{array}$ & $\begin{array}{c}1015.228 \\
(31.863)\end{array}$ & $\begin{array}{c}3663.619 \\
(60.528)\end{array}$ & $\begin{array}{c}1961.368 \\
(44.287)\end{array}$ & $\begin{array}{c}1404.755 \\
(37.480)\end{array}$ & $\begin{array}{c}1526.904 \\
(39.076)\end{array}$ & $\begin{array}{c}7233.178 \\
(85.048)\end{array}$ \\
\hline II & & $\begin{array}{l}540.052 \\
(23.239)\end{array}$ & $\begin{array}{l}1994.041 \\
(44.655)\end{array}$ & $\begin{array}{l}1713.813 \\
(41.398)\end{array}$ & $\begin{array}{c}1924.189 \\
(43.866)\end{array}$ & $\begin{array}{l}893.004 \\
(29.883)\end{array}$ & $\begin{array}{c}3623.092 \\
(60.192)\end{array}$ & $\begin{array}{r}4146.079 \\
(64.390)\end{array}$ \\
\hline III & & & $\begin{array}{l}823.007 \\
(28.688)\end{array}$ & $\begin{array}{c}4785.905 \\
(69.180)\end{array}$ & $\begin{array}{c}1446.560 \\
(38.034)\end{array}$ & $\begin{array}{c}2187.775 \\
(46.774)\end{array}$ & $\begin{array}{l}1121.016 \\
(33.482)\end{array}$ & $\begin{array}{c}7506.083 \\
(86.638)\end{array}$ \\
\hline $\mathbf{I V}$ & & & & $\begin{array}{l}841.803 \\
(29.014)\end{array}$ & $\begin{array}{c}4051.651 \\
(63.653)\end{array}$ & $\begin{array}{c}1476.837 \\
(38.430)\end{array}$ & $\begin{array}{c}7955.955 \\
(89.196)\end{array}$ & $\begin{array}{c}2001.969 \\
(44.743)\end{array}$ \\
\hline $\mathbf{V}$ & & & & & $\begin{array}{l}733.945 \\
(27.091)\end{array}$ & $\begin{array}{c}2886.655 \\
(53.728)\end{array}$ & $\begin{array}{c}2515.268 \\
(50.152)\end{array}$ & $\begin{array}{c}4841.563 \\
(69.581)\end{array}$ \\
\hline $\mathbf{V I}$ & & & & & & $\begin{array}{c}0.000 \\
(0.000)\end{array}$ & $\begin{array}{c}4106.568 \\
(64.083)\end{array}$ & $\begin{array}{c}4392.902 \\
(66.279)\end{array}$ \\
\hline VII & & & & & & & $\begin{array}{c}0.000 \\
(0.000)\end{array}$ & $\begin{array}{l}11832.909 \\
(108.779)\end{array}$ \\
\hline VIII & & & & & & & & $\begin{array}{c}0.000 \\
(0.000)\end{array}$ \\
\hline
\end{tabular}


Table.4 Mean values of eight clusters estimated by Tocher's method from 48 rice genotypes

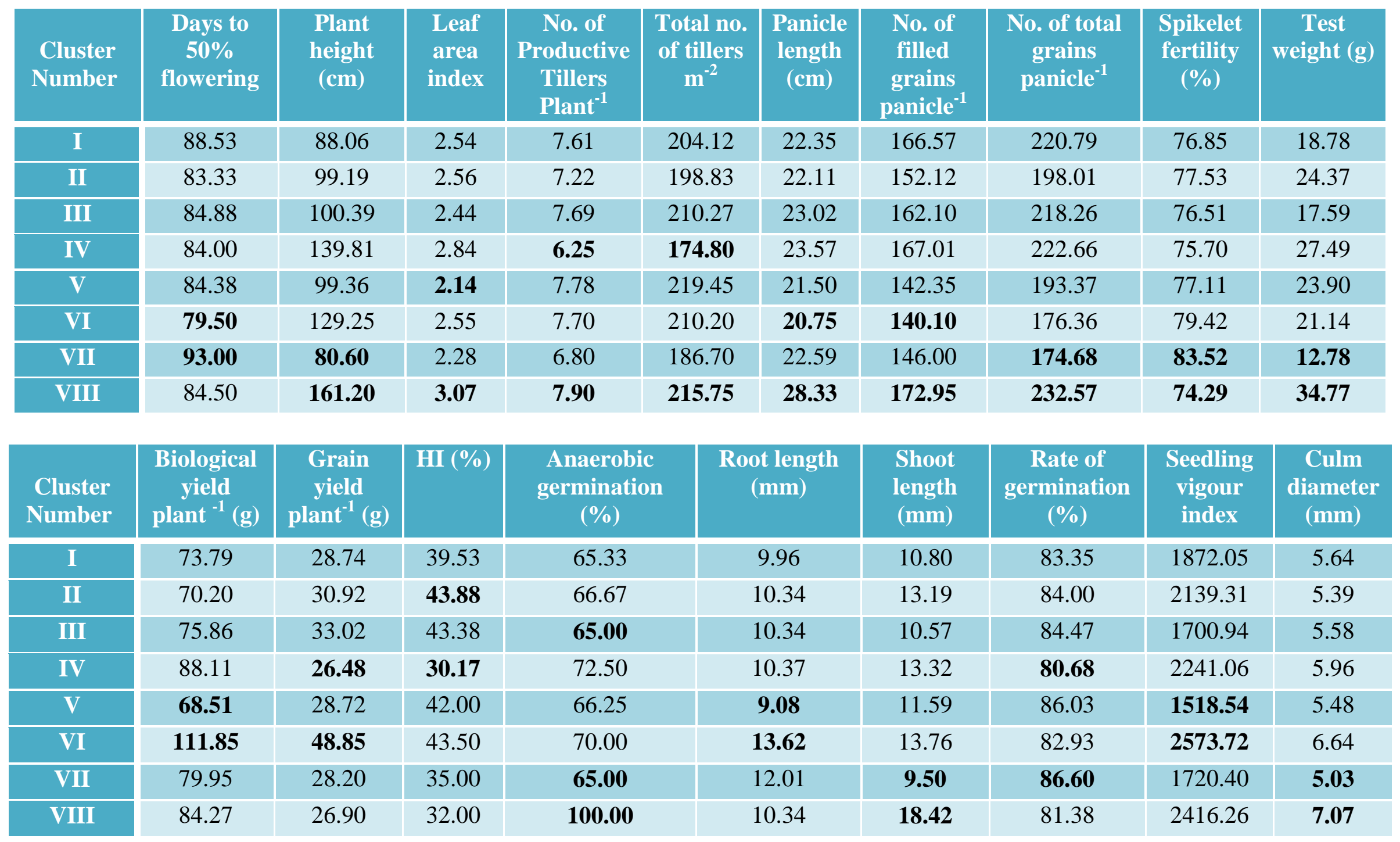

Note: Bold figures indicate minimum and maximum values 
The average intra and inter cluster $\mathrm{D}^{2}$ values were estimated as per the procedure given by Singh and Chaudhary (1977) and were presented in the Table 3. The maximum intra cluster distance was 841.80 in cluster IV followed by 823.07 in cluster III followed by 733.94 in cluster $\mathrm{V}$ followed by 540.05 in cluster II and 418.66 in cluster I. While, it was zero for clusters VI, VII, VIII. The intraand inter- cluster distances revealed that intercluster distance values were greater than intra-cluster distance values. The high intracluster distance in cluster IV indicates the presence of wide genetic diversity among the genotypes present within this cluster.

In the present study, inter-cluster distances were worked out considering 19 characters and these distances ranged from 893.00 (between cluster II and VI) to 11832.91 (between cluster VII and VIII). The intercluster distance was maximum between cluster VII and VIII, followed by cluster IV and VII, cluster III and VIII, cluster I and VIII, cluster V and VIII, cluster VI and VIII and cluster II and VIII. This suggested that there is wide genetic diversity between these clusters. Based on these studies, crosses can be made between genotypes of these clusters to obtain desirable transgressive segregants.

The cluster mean values for 19 characters are presented in Table 4. Higher mean values for number of productive tillers per plant were seen in cluster VIII and V; higher means for leaf area index were observed in clusters VIII and IV; higher means for panicle length were observed in clusters VIII and IV; higher means for spikelet fertility were observed in clusters VII and VI; higher means for test weight were observed in clusters VIII and IV; higher means for vigour index were seen in cluster VI and VIII which are major contributors in improving grain yield in rice under direct seeding conditions. Based on mean values, series of crosses in diallel analysis may prove highly successful for genetic improvement of the above mentioned traits.

Shafina et al., (2014) and Bose et al., (2011) was also studied genetic divergence in direct seeded rice and reported similar results.

Choice of the particular cluster and selection of particular genotype from selected cluster are the two important points to be considered before initiating the crossing programme. The hybrids between varieties of different clusters will express high heterosis and give more useful segregants (Tripathi et al., 2013).

\section{References}

Bose, L.K., Singh, O.N., Subudhi, H.N and Rao, G.J.N. 2011. Genetic diversity in direct seeded aerobic rice. International Journal of Agricultural Sciences. 7 (2): 321-324.

http://ricestat.irri.org

Ismail, A.M., Ella, E.S., Vergara, G.V and Mackill, D.J. 2009. Mechanisms associated with tolerance to flooding during germination and early seedling growth in rice (Oryza sativa). Annals of Botany. 103:197-209.

Ladha, J.K., Singh, Y., Erenstein, $\mathrm{O}$ and Hardy, B. 2009. Integrated Crop and Resource Management in the RiceWheat System of South Asia. pp. 69108.

Mahalanobis, P.C. 1936. A statistical study at Chinese head measurement. J. Asiaticsociety Bengal. 25: 301:77.

Pandey, P and Anurag P.J. 2010. Depiction of genetic divergence in rice. Advances in Agriculture and Botanics-Bioflux. 2 (3): 285-291.

Rao, C. R. 1952. Advanced Statistical Methods in Brometrical Research. John Wiley and Sons publishers, New York. 
Sandhya, M., Sunita Kumari and Suresh Babu. 2015. Estimation of genetic divergence among elite genotypes of rice (oryza sativa L.). The Ecoscan. 9(3\&4): 923-925.

Shafina, H., Pradhan, S.K and Singh, O.N. 2014. Genetic diversity in direct seeded aerobic rice. Oryza. 51 (2): 121-124.

Shukla, V., Singh, S., Singh, H and Pradhan, S.K. 2006. Multivariate analysis in tropical japonica "New plant type" rice (Oryza sativa L.). Oryza. 43(3): 203207.
Soni, S.K., Yadav, V.K and Ram, T. 2014. Genetic divergence analysis in tropical japonica and indica rice lines (Oryza sativa L.). Plant Archives. 14 (1): 449453.

Tripathi, A., Bisen, R., Ahirwal, R.P, Paroha, S., Sahu, R and Ranganatha, A.R.G. 2013. Study on genetic divergence in Sesame (Sesamum indicum L.) Germplasm based on morphological and quality traits. The Bioscan. 8(4): 13871391.

\section{How to cite this article:}

Ravikanth Bendi, P.V. Satyanarayana, N. Chamundeswari, Y. Ashoka Rani, V. Srinivasa Rao and Ratna Babu, D. 2018. Study of Genetic Diversity among Elite Genotypes of Rice (Oryza sativa L.) for Direct Seeding Traits. Int.J.Curr.Microbiol.App.Sci. 7(09): 1384-1390. doi: https://doi.org/10.20546/ijcmas.2018.709.166 